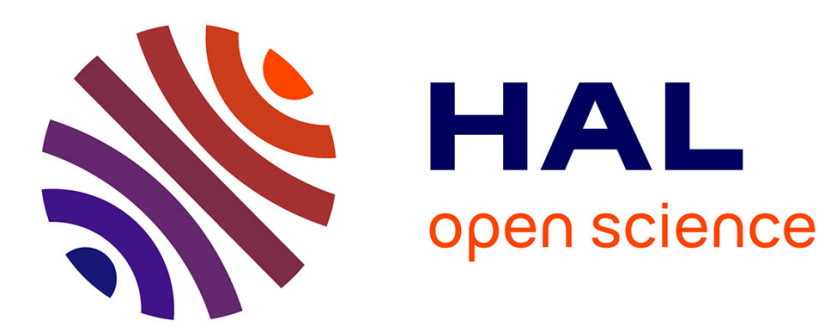

\title{
Total nitrogen dioxide at the Arctic Polar Circle since 1990
}

\author{
Florence Goutail, Jean-Pierre Pommereau, Alain Sarkissian, Esko Kyrö, \\ Valery Dorokhov
}

\section{- To cite this version:}

Florence Goutail, Jean-Pierre Pommereau, Alain Sarkissian, Esko Kyrö, Valery Dorokhov. Total nitrogen dioxide at the Arctic Polar Circle since 1990. Geophysical Research Letters, 1994, 21 (13), pp.1371-1374. 10.1029/93GL01783 . insu-03527645

\section{HAL Id: insu-03527645 https://hal-insu.archives-ouvertes.fr/insu-03527645}

Submitted on 21 Jan 2022

HAL is a multi-disciplinary open access archive for the deposit and dissemination of scientific research documents, whether they are published or not. The documents may come from teaching and research institutions in France or abroad, or from public or private research centers.
L'archive ouverte pluridisciplinaire HAL, est destinée au dépôt et à la diffusion de documents scientifiques de niveau recherche, publiés ou non, émanant des établissements d'enseignement et de recherche français ou étrangers, des laboratoires publics ou privés.

$$
\text { Copyright }
$$




\title{
Total nitrogen dioxide at the Arctic polar circle since 1990
}

\author{
Florence Goutail, Jean Pierre Pommereau, Alain Sarkissian \\ Service d'Aéronomie du CNRS, France
}

Esko Kyro

Sodankyla Observatory, Finland

Valery Dorokhov
Central Aerological Observatory, Russia

Abstract. Daily ground-based $\mathrm{NO}_{2}$ column measurements have been conducted with UV-visible SAOZ diode-array spectrometers at Sodankyla in northern Finland since January 1990 and at 3 additional stations during EASOE. Inspection of the data indicates: a total $\mathrm{NO}_{2}$ reduction by $30 \%$ by the Pinatubo aerosol in spring and summer 1992 compared to the previous years; a poor correlation in winter with potential vorticity indicative of motion of the vortex and of advection of air from mid-latitude, frequent during EASOE; an absence of significant global denitrification by sedimentation of nitric acid on PSC particles inside the vortex; and a high correlation between total $\mathrm{NO}_{2}$ and 30 $50 \mathrm{hPa}$ temperature. The latter is unexpected in winter 199192 , since most of $\mathrm{NOx}\left(\mathrm{NO}+\mathrm{NO}_{2}+\mathrm{ClONO}_{2}+2 \mathrm{~N}_{2} \mathrm{O}_{5}\right)$ at the altitude of the aerosol layer should have been converted into liquid nitric acid. This is expected to revert only slowly to NOx at high latitude in winter. The correlation suggests a temperature dependent saturation of the aerosol water / sulfuric acid droplets and / or a temperature dependent mechanism of restitution of NOx to the gas phase.

\section{Introduction}

Because of its ability to convert $\mathrm{ClO}$ into $\mathrm{ClONO}_{2}$ in the stratosphere, that is to convert active chlorine compounds and thus to inhibit ozone destruction, $\mathrm{NO}_{2}$ is one of the key parameters in the polar ozone depletion issue. However, its amount and variation in polar regions depend on many parameters: 1) dynamics, because of a possible advection of NOx species from other latitudes, 2) duration of the day, because of the photolysis of the NOx reservoirs and of the radicals themselves, 3) microphysics and heterogeneous chemistry on PSC, because of a possible removal of NOx from the stratosphere by sedimentation, 4) temperature, because of the dependence of all the above parameters to temperature and 5) volcanic aerosols in 1991- 92 after the eruption of Mount Pinatubo, which are able to convert NOx into $\mathrm{HNO}_{3}$ in the lower stratosphere, and then to deplete their concentration.

In order to investigate the influence of the above parameters on $\mathrm{NO}_{2}$ column variations, ground-based UV-

Copyright 1994 by the American Geophysical Union.

Paper number 93GL01783

0094-8534/94/93GL-01783\$03.00 visible spectrometers were installed in the Arctic region at the latitude of the polar circle.

After first tests on a campaign basis begun in 1988 (Pommereau and Goutail, 1988), a SAOZ diode-array spectrometer, able to measure $\mathrm{NO}_{2}$ columns from the ground twice a day at twilight, was installed permanently at Sodankyla in northern Finland $\left(67^{\circ} 20 \mathrm{~N}, 2^{\circ} \mathrm{E}\right)$ in January 1990. For the purpose of EASOE, the above observations were reinforced by the deployment of 3 additional similar instruments at Scoresbysund in Greenland $\left(71^{\circ} \mathrm{N}, 21^{\circ} \mathrm{W}\right)$, onboard the Norwegian weather ship Polarfront in station in the northern Atlantic $\left(66^{\circ} \mathrm{N}, 02^{\circ} \mathrm{E}\right)$ and on the other side of the hemisphere, at Zhigansk $\left(66^{\circ} 40,123^{\circ} \mathrm{E}\right)$ in eastern Siberia. The data available from Sodankyla since 1990 and Zhigansk in winter 1991-92, will be used together with meteorological information from ECMWF, to investigate the relationship between $\mathrm{NO}_{2}$ columns and dynamical and photochemical parameters.

\section{Measurements}

SAOZ is a $300-600 \mathrm{~nm}, 0.65 \mathrm{~nm}$ FWHM resolution, 512 elements diode array spectrometer looking at sunlight scattered by the atmosphere at zenith (Pommereau and Goutail, 1988). Measurements are performed every 5 minutes from sunrise until sunset. The data analyzed in real time are transmitted by satellite collection (ARGOS) for operational purpose and recorded onto diskettes sent by mail for further analysis. Results presented below are those of the reanalysis.

Nitrogen dioxide is measured by a differential absorption method in the visible bands between 412 and $515 \mathrm{~nm}$, on 17 narrow features (1 - $5 \mathrm{~nm}$ large) simultaneously. Slant columns are determined after removal of the signatures of other absorbers $\left(\mathrm{O}_{3}, \mathrm{O}_{4}, \mathrm{H}_{2} \mathrm{O}\right)$ present in the spectra, by an iterative procedure.

In order to retrieve the constituent vertical total column, slant columns are divided by an air mass factor (AMF) which corresponds to the enhancement of slant optical path compared to the vertical. AMFs are calculated with a simple scattering model with $\mathrm{NO}_{2}$ profiles measured from balloon at mid latitude. AMF is postulated identical at sunset and sunrise and not to vary during the year. Its value is 17.7 at $90^{\circ} \mathrm{SZA}$ and $440 \mathrm{~nm}$.

Each twilight vertical column results from an average of about 5 measurements performed between $86^{\circ}$ and $91^{\circ}$. The precision (one standard deviation) of the vertical column estimated from the spectral least squares fit on the $17 \mathrm{NO}_{2}$ 
bands and for an average of 5 measurements during twilight, is of $1 * 1014 \mathrm{~mol} . \mathrm{cm}^{-2}$. Uncertainties of absolute crosssections introduce a systematic error of $15 \%$. The ones of AMF, not included above, will be discussed later. Recent intercomparison with totally different instrument / resolution / sampling / software / field of view in the frame of the Network for Detection of Stratospheric Changes (NDSC), have shown discrepancies not exceeding 21014 mol.cm-2 when converted into vertical columns, that is consistent with the above figure. Tropospheric pollution can also contribute. Large $\mathrm{NO}_{2}$ column increases occur sometimes mostly in northern Scandinavia (Pommereau and Goutail, 1988) but never in Siberia. They are caused by a combination of surface pollution and multiple scattering enhancement. The largest are easy to detect and remove by looking at simultaneous spikes in $\mathrm{O}_{4}$ absorption. However, small ones can still be present in the data set of Sodankyla.

\section{Experimental data}

Three years of permanent observations at Sodankyla in Finland are displayed in figure 1: morning and evening $\mathrm{NO}_{2}$ vertical columns from which the largest polluted days have been removed in panel (a); difference between evening and morning in panel (b); temperature at $50 \mathrm{hPa}$ measured by radio-sounding in panel (c).

An enlargement of the above observations at Sodankyla in winter 1991-92 together with those conducted at the same latitude, except on the other side of the hemisphere at Zhigansk, is shown in figure 2. Panel (a): morning and evening columns; panel (b) diurnal variation; panel (c) temperature at 10,30 and $50 \mathrm{hPa}$ from ECMWF; panel (d) potential vorticities (PV) at $475 \mathrm{~K}$ (approx. $20 \mathrm{~km}$ ), $550 \mathrm{~K}$ (approx. $22 \mathrm{~km}$ ) and $700 \mathrm{~K}$ (approx. $27 \mathrm{~km}$ ), indicative of the motion of the vortex (high $\mathrm{PV}$ inside). $\mathrm{NO}_{2}$ columns resulting from integration of vertical profiles measured from balloons above Sodankyla by solar occultation with a similar UV-vis spectrometer (Pommereau and Piquard, this issue), are also shown in panel (a): open circles for morning flights and close circles for the evening. Measurements at the two other European Arctic stations are not shown because of lack of space. They are very similar to the ones of Sodankyla.

Figure 1 demonstrates the large $\mathrm{NO}_{2}$ seasonal variation at polar circle (maximum in summer, minimum in winter) and the semi-annual cycle of the amplitude of the diurnal variation, because of the absence of $\mathrm{N}_{2} \mathrm{O}_{5}$ photolysis during winter and of the inhibition of $\mathrm{N}_{2} \mathrm{O}_{5}$ formation during the polar day in summer. Compared to 1990 and 1991, the summer column maximum is reduced by $30 \%$ in 1992 , as well as the spring amplitude of the diurnal cycle at similar temperature. This is attributed to volcanic aerosol from Mount Pinatubo which arrived first in September 1991 above Sodankyla, deepened progressively until January 1992 (Sarkissian et al., this issue) and deepened again after the vortex moved away from the European Arctic (Kastad et al., this issue). At smaller time scale, spikes related to tropospheric pollution are often present in Scandinavia but not in Siberia. Large variations persistent for a few days or weeks also appear very similar to the ones reported by Noxon (1979) and known as Noxon's "cliff". They correlate apparently to stratospheric temperature variation (end 1990).

Figure 2 demonstrates that balloon and ground-based $\mathrm{NO}_{2}$ columns at Sodankyla are consistent, but at one occasion on January 30. Both instruments and their spectral analysis being identical, systematic errors are common. An AMF of 17.7 at $90^{\circ} \mathrm{SZA}$ is then consistent in winter.

The large difference between Sodankyla, located in the cold stratosphere of the European Arctic, and Zhigansk, in the warm stratosphere of the Siberian Arctic, is striking in figure 2 . The quality of the data was checked carefully by looking at the complete diurnal cycles at high sun at noon at spring. There is no doubt: on average in winter, the $\mathrm{NO}_{2}$ column is larger by a factor of 3 at Zhigansk. The reality of this effect is confirmed by the diurnal variation, small until early February at Sodankyla and already present from January 10, at Zhigansk. This indicates that not only total $\mathrm{NO}_{2}$ but also $\mathrm{N}_{2} \mathrm{O}_{5}$ was larger above the eastern side of the Northern hemisphere in winter, in and outside the vortex.

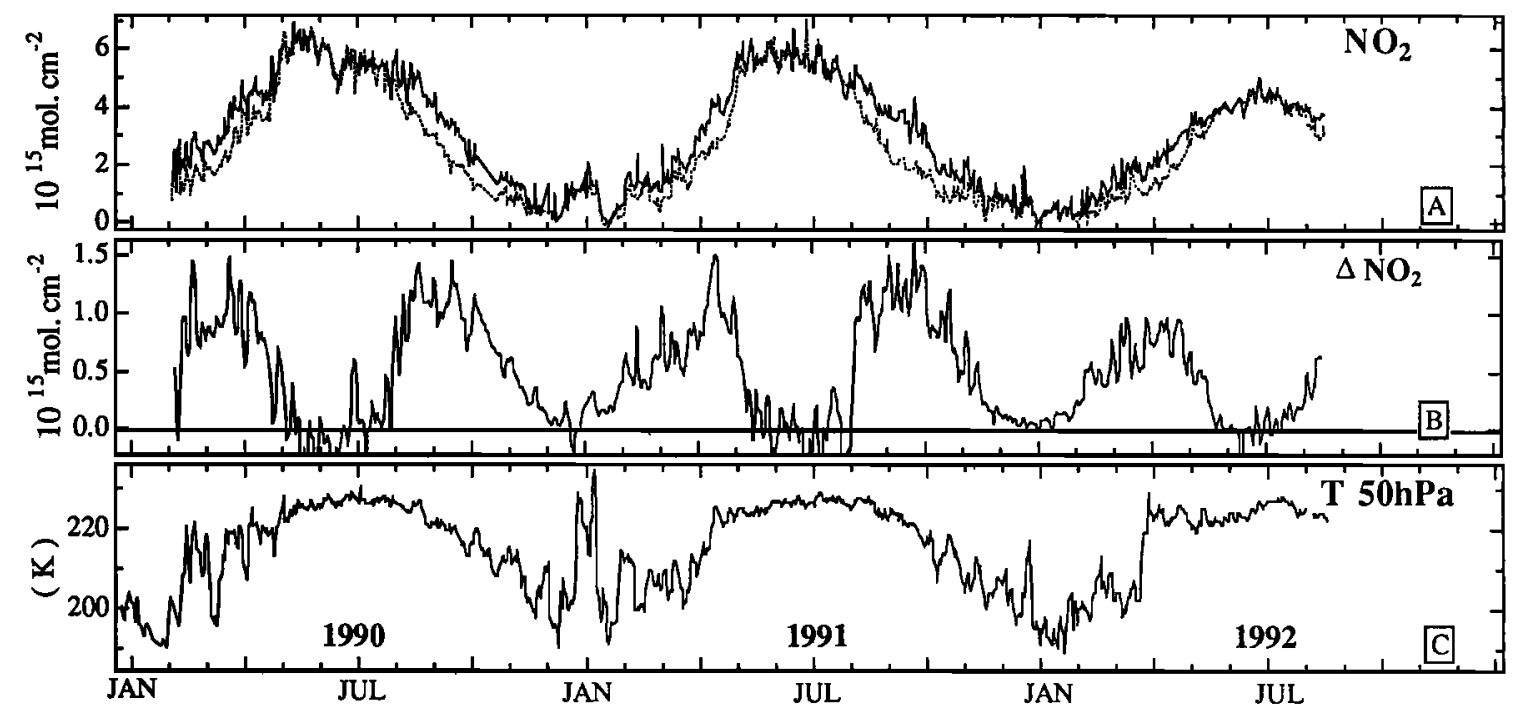

Fig 1. Three years observations at Sodankyla in northern Finland. Panel (A): $\mathrm{NO}_{2}$ vertical columns measured twice a day, on the morning (-..... lower curve) and the evening (—upper curve). Panel (B): difference between evening and morning (proportional to 2 times $\Delta \mathrm{N}_{2} \mathrm{O}_{5}$ ). Panel (C): temperature from daily radio-soundings at the same station. 


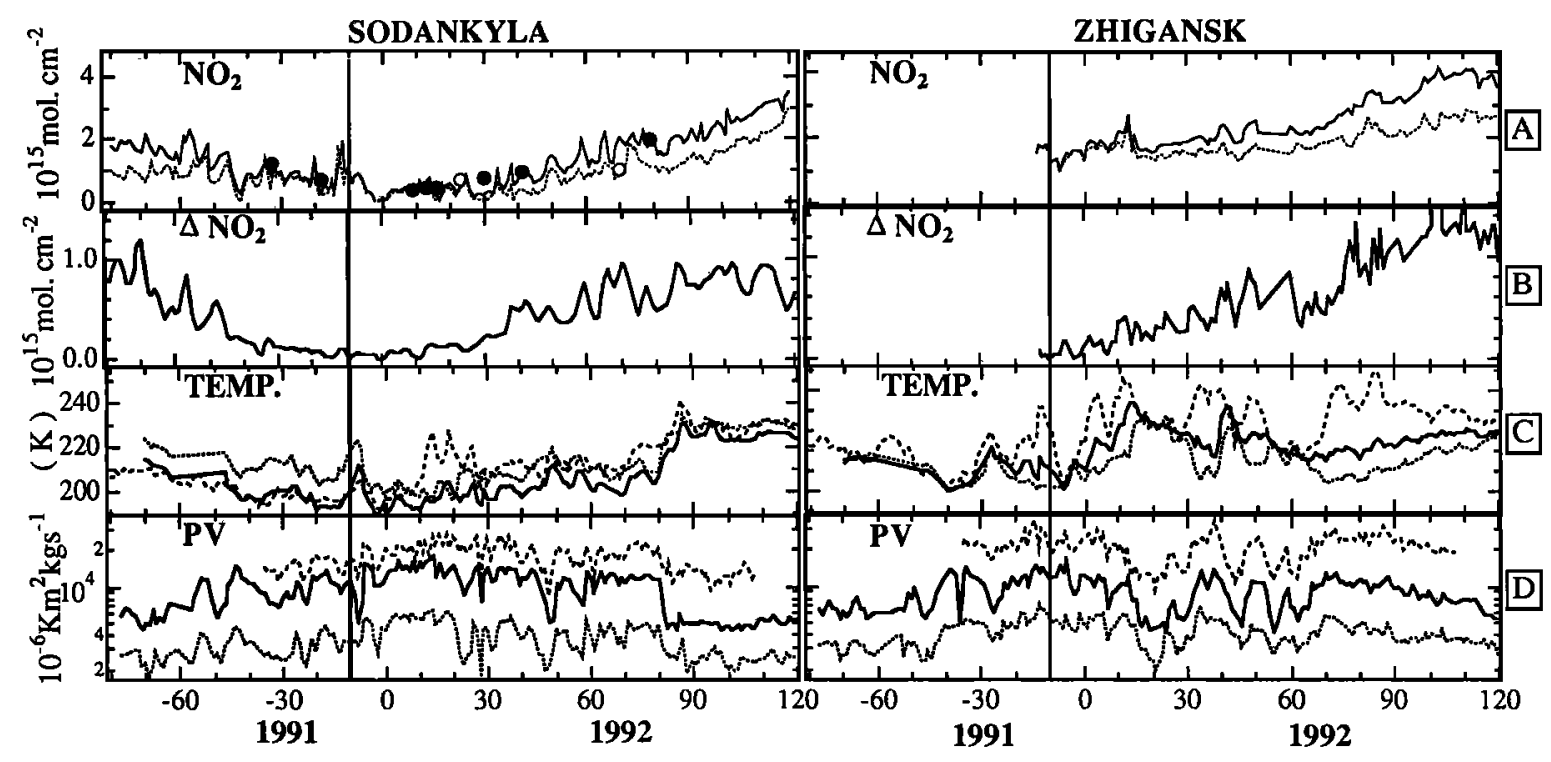

Fig 2. Measurements conducted during EASOE from October 1991 until April 1992 at Sodankyla (left) and Zhigansk in eastern Siberia (right) The vertical bar indicates the date of the solstice (21 December). Panel (A): morning (-......) and evening $(\longrightarrow) \mathrm{NO}_{2}$ columns; Panel (B) evening-morning difference; Panel (C) temperature at $10 \mathrm{hPa}(---), 30 \mathrm{hPa}(\longrightarrow)$ and $50 \mathrm{hPa}$ (-....) from ECMWF; Panel (D) potential vorticity (PV) at $700 \mathrm{~K}(--), 550 \mathrm{~K}(\longrightarrow)$ and $475 \mathrm{~K}(\cdots \cdots \cdots \cdot)$ in logarithmic ordinate.

The same is true also at spring in April, but in that case there is an explanation. By the end of March, the vortex moved rapidly away from the European Arctic toward Siberia and the aerosol layer extended in both density (x2) and altitude (up to $25 \mathrm{~km}$ ) at Sodankyla (Kastad et al., this issue). In contrast, Zhigansk remained inside the vortex, up to the end of April. The difference in $\mathrm{NO}_{2}$ columns between the 2 stations at Spring can thus be related to a difference in aerosol loading.

In winter and spring, $\mathrm{NO}_{2}$ variations do not correlate with $\mathrm{PV}$ indicative of the motion of the vortex as observed at our station of Dumont d'Urville in Antarctica. There is no apparent difference between the inside and the outside, except after the final warming as said above. Zhigansk and Sodankyla both experienced the vortex and the outside during the winter. There is no $\mathrm{NO}_{2}$ signature which would correspond to an advection of air from mid-latitude marked by low PV, e.g. during the second half of January above Sodankyla and which resulted in the lowest ozone columns recorded during the winter.

The 30-50 hPa temperatures seem to correlate best with the $\mathrm{NO}_{2}$ variations, but not the $10 \mathrm{hPa}$ one: a warming at this uppermost level in mid January at Sodankyla had no consequence on $\mathrm{NO}_{2}$. The lowest $\mathrm{NO}_{2}$ column ever recorded during the campaign was the one observed on 29 December at Sodankyla on the coldest day, where PSC, an ozone minihole and a temperature minimum as low as $-92^{\circ} \mathrm{C}$ at $23 \mathrm{~km}$ were reported (Sarkissian et al., this issue). Warming at 30 and $50 \mathrm{hPa}$ in winter are accompanied by $\mathrm{NO}_{2}$ increases (e.g. end of 1990, 18-24 December 1991 at Sodankyla at the solstice when the sun remained below the horizon at noon, or 9-13 January at Zhigansk). Finally, similar $\mathrm{NO}_{2}$ columns are observed at Zhigansk and Sodankyla at similar $30-50 \mathrm{hPa}$ temperatures at the same date and thus same illumination. This occurred twice: on December 22-23, 1991 (about $1 * 1015 \mathrm{~mol}$. $\mathrm{cm}^{-2}$ at around $205 \mathrm{~K}$ at the two stations) and on March $10-20,1992$ (about
$2 * 1015 \mathrm{~mol} . \mathrm{cm}^{-2}$ around $220 \mathrm{~K}$ ). Most of the observed $\mathrm{NO}_{2}$ (and $\mathrm{N}_{2} \mathrm{O}_{5}$ ) variations at a given station or between the two stations in winter, appear then to correlate best with temperature variations of the lower stratosphere.

\section{Discussion}

$A M F$ factors. AMF used to convert slant into vertical columns, are derived from calculations assuming an $\mathrm{NO}_{2}$ vertical distribution similar to that of mid latitude. New calculations with actual arctic $\mathrm{NO}_{2}$ profiles measured from balloons, show that the current AMF might be sometimes overestimated in winter. This is demonstrated by the comparison between ground-based and balloon integrated total columns shown in figure 2. In winter, the weaker $\mathrm{NO}_{2}$ layer at high altitude makes the lower stratosphere contribute relatively more. The largest difference occured on January 30,1992 in presence of an $\mathrm{NO}_{2}$ layer around $15 \mathrm{~km}$ (Pommereau and Piquard, this issue).

Another concern is the consequence of volcanic aerosol on retrieved $\mathrm{NO}_{2}$ columns. For interpreting their observations in New Zealand in 1992, Johnston et al. (1992) have assumed a conservative possible AMF reduction of $20 \%$ because of the increased altitude of the scattering height at twilight. Single scattering calculations with actual $\mathrm{NO}_{2}$ and aerosol optical thickness measured with SAOZ balloons, indicate an AMF reduction of few percent. Multiple scattering calculations by a Monte-Carlo method (Perliski and Solomon, 1992) concluded also to a very small contribution. The comparison of balloon and ground based total columns, this after, confirm. The consequence of the Pinatubo aerosol layer on $\mathrm{NO}_{2} \mathrm{AMF}$ at $440 \mathrm{~nm}$ and $90^{\circ} \mathrm{SZA}$ is not detectable, at least before the arrival of the thicker and higher altitude cloud, after the final warming.

Heterogeneous conversion of NOx onto volcanic aerosol. A $40 \%$ apparent reduction of $\mathrm{NO}_{2}$ columns above New Zealand in austral winter and spring 1991 was reported by 
Johnston et al., (1992). Here we report $30 \%$ at spring after the final warming and in summer and a negligible effect in winter in the Arctic. Because of the small contribution of the AMF reduction as said above and also of the small effect of additional sunlight attenuation (Perliski and Solomon, 1992), most of this is thought to be the consequence of an heterogeneous conversion of $\mathrm{NOx}$ into $\mathrm{HNO}_{3}$ on sulfate aerosol (Lateltin et al., this issue). The difference between the two hemispheres could relate to the denser and higher aerosol cloud in the South (Johnston et al., 1992).

Relation between $\mathrm{NO}_{2}$ columns and stratospheric transport. After Noxon, (1979), it was generally assumed that most of the observed $\mathrm{NO}_{2}$ day to day fluctuations in winter were related to advection of air which had been previously more (south) or less (north) exposed to sunlight and that a fast transition between the two regimes explains the "cliff" which was sometimes reported. Inspection of the relation between $\mathrm{PV}$ at any level and $\mathrm{NO}_{2}$ in figure 2, does not support this idea at least for 1991-92. Advection from lower latitude marked by low PV episodes at all levels, are not correlated with larger $\mathrm{NO}_{2}$ columns. However, this might be due in 1991-92 to the large denoxification by aerosol at mid latitude which would result in a weaker latitudinal NOx gradient.

Denitrification. Inside the Antarctic vortex, NOx species are removed from the stratosphere by heterogeneous conversion into $\mathrm{HNO}_{3}$ onto PSC particles, which are then sedimented (Mount et al, 1987). Lower $\mathrm{NO}_{2}$ columns as well as smaller diurnal variations indicative of a reduction of $\mathrm{N}_{2} \mathrm{O}_{5}$ and thus of total NOx, is a common feature when the vortex approaches our station at Dumont d'Urville in Antarctica at spring. Nothing similar was observed during EASOE in the Arctic. Therefore it can be concluded that nothing special - denitrification or larger denoxification happened inside the vortex in the Arctic in winter 1991-92.

$\mathrm{NO}_{2}$ - Temperature relation. $\mathrm{NO}_{2}$ columns variations are found to correlate the closest with $30-50 \mathrm{hPa}$ temperatures in winter. Such correlation was already reported in the Arctic winter 1988, which was then partly understood only from gas phase chemistry considerations (Pommereau and Goutail, 1988). In 1991-92, volcanic aerosol surfaces were large enough to convert most of NOx up to $22-24 \mathrm{~km}$ into $\mathrm{HNO}_{3}$ in the liquid droplets within a few days (Lateltin et al., this issue). The question is then to understand the presence of larger $\mathrm{NO}_{2}$ columns at warm temperature. This would suggest a temperature dependent saturation of water / sulfuric acid droplets and a larger $\mathrm{HNO}_{3}$ photolysis rate or a temperature dependent mechanism of restitution of NOx to the gas phase. Because of the absence of denitrification and of the strong adiabatic warming at each circling around the vortex, such NOx release at warm temperature, would have been able to prevent an ozone depletion in winter 1991-92.
Acknowledgements. This work was supported by European Economic Community in the frame of the EASOE campaign (Grants STEP-0013 and STEP-0141), by the French Programme Atmosphère Moyenne (PAMOY) and the Russian Federation Committee for Hydrometeorology, which are gratefully acknowledged.

\section{References}

Johnston, P. V., R. L. McKenzie, J. G. Keys and W. A. Matthews, 1992: Observations of depleted stratospheric $\mathrm{NO}_{2}$ following the Pinatubo volcanic eruption. Geophys. Res. Lett., 19, 211-213, 1992.

Kastad, B. A., G. Braathen, A. Dahlback, R. Neuber, N. Larsen, R. Fabian and S. Larsen, Improved Airmass Factors as obtained from Aerosols Lidar Measurements, Geophys. Res. Lett., same issue.

Lateltin, E., J. P. Pommereau, H. LeTexier, M. Pirre and R. Ramaroson, Perturbation of stratospheric nitrogen dioxide by volcanic aerosol in the Arctic, Geophys. Res. Lett., same issue.

Mount, G., R. Sanders, A. Schmeltekopf and S. Solomon, Visible spectroscopy at McMurdo Station, Antarctica: 1. Overview and daily variations of $\mathrm{NO}_{2}$ and $\mathrm{O}_{3}$, austral spring, 1986, J. Geophys. Res., 92, 8320-8328, 1987.

Noxon, J.F., Stratospheric $\mathrm{NO}_{2} 2$ ) Global Behaviour, $\mathbf{J}$ Geophys. Res., 84, 5067-5076, 1979

Perliski L. M. and S. Solomon, Radiative influences of Pinatubo aerosols on twilight observations of $\mathrm{NO}_{2}$ column abundances, Geophys. Res. Lett., 19, 1923-1926, 1992.

Pommereau, J. P. and F. Goutail, $\mathrm{O}_{3}$ and $\mathrm{NO}_{2}$ ground-based measurements by visible spectrometry during Arctic winter and spring 1988, Geophys. Res. Lett., 15, 891-894, 1988.

Pommereau, J. P. and J. Piquard, Ozone, Nitrogen dioxide and aerosol vertical distributions by UV-visible solar occultation from balloons, Geophys. Res. Lett., same issue.

Sarkissian, A., J. P. Pommereau, F. Goutail and E. Kyrö, PSC and volcanic aerosol observations during EASOE by UV-visible ground-based spectrometry, Geophys. Res. Lett., same issue.

F. Goutail, J. P. Pommereau and A. Sarkissian, Service d'Aéronomie, B.P. n³, 91371 Verrières le Buisson, France.

(Received: December 4, 1992; Revised: February 17, 1993; Accepted: June 30, 1993) 